\title{
TRANSFER AND EXPORT \\ IN ARCHITECTURAL HISTORY
}

\author{
THREE CASE STUDIES \\ FROM THE CARPATHIAN BASIN
}

\author{
ZSUZSANNA EMÍLIA KISS ${ }^{*}$ - GERGÖ MÁTÉ KOVÁCS** - MARTIN PILSITZ*** \\ "Lecturer. Department of History of Architecture and Monument Preservation, Faculty of Architecture, \\ BME K II. 82, Mủegyetem rkp. 3, 1111 Budapest, Hungary. E-mail: emilia@eptort.bme.hu \\ ${ }^{* *} \mathrm{PhD}$, research fellow. Department of History of Architecture and Monument Preservation, \\ Faculty of Architecture, BME K II. 82, Müegyetem rkp. 3, 1111 Budapest, Hungary. \\ E-mail: kovacsmg@eik.bme.hu \\ ${ }^{* * *} \mathrm{PhD}$, researcher. Department of History of Architecture and Monument Preservation, \\ Faculty of Architecture, BME K II. 82, Müegyetem rkp. 3, 1111 Budapest, Hungary. \\ E-mail: pilsitz.martin@gmail.com
}

Transferring a building type from its original context (in the sense of genius loci) into a foreign environment for which it was not intended, is equivalent to transplantation. As the case studies show, the evoked response does not necessarily have to be negative. Rather, this phenomenon is to be understood as an external impulse that influences regional architectural development.

This paper examines the principle of the architectural-historical process in the territory of the Carpathian Basin in three periods. The case studies of the article are derived from the architecture of the Roman era $\left(1^{\text {st }}-5^{\text {th }}\right.$ centuries CE), the Ottoman era $\left(16^{\text {th }}-17^{\text {th }}\right.$ centuries $\left.C E\right)$ and the historical industrial architecture of the era of Austro-Hungarian Monarchy (19 $19^{\text {th }}-20^{\text {th }}$ centuries CE), since the Carpathian Basin, the interference territory of Western and Eastern Europe, Northern Europe and the Balkans, was under the influence of states with centres in a different area. These being the Roman Empire, the Ottoman Empire and the Austro-Hungarian Monarchy, all having a determinative influence on the following period's architecture.

Consequently, the influence of a relatively different culture with global dimensions can be examined within a regional context. This perspective leads to the actual question of architectural history: how the interaction of local and global architectural tendencies and features, the relationship between the centre, semi-periphery and periphery influence the examination of architectural processes and preservation of unique values. By examining the case studies, the paper establishes the categories of architectural transfer and architectural export. The aim of the paper is to stimulate discussions through further examples.

Keywords: architectural transfer, industrial heritage, temple of the Capitoline Triad, Ottoman architecture, Carpathian Basin

\# This work was supported by the National Cultural Fund of Hungary (NKA) under Grant Number $101108 / 547$.

$\triangle$ Corresponding author.

(C) 2020 The Authors 


\section{INTRODUCTION}

The territory of the Carpathian Basin forms a topographically discrete unit set in the south-eastern part of the Central European landscape, one surrounded by geographic boundaries - the Carpathian Mountains and the Alps. The plains, which mainly determine the geographical system of the area, are divided by the rivers Danube and Tisza. The area, which has ideal natural conditions, is rich in natural resources and surrounded by a geographical defence system consisting of a chain of mountains, is located between the Balkans and the northern European plains, on the border of the steppes towards Asia, and western Europe. Historical trading routes (the Amber Road) crossed this area as did the important fortification and route system (the limes) of the Eastern boundaries of the Roman Empire, and the route of the Ottomans from Belgrade to the West near the Danube. Consequently, the land has always been the target of conquests from different directions - from the East, the Southern territories of the Balkans as well as from the West.

This special, geographically framed crossroads of different cultures and religions has been in both a central - mainly when the Kingdom of Hungary was a potential empire - and peripheral situation as in the age of the Roman Empire or during the Ottoman Era. Moreover, these two phenomena periodically changed as a potentially central situation was followed by one where the area was under the influence of another empire in a peripheral status. This dynamic change of external influences and prosperous central situation resulted in the uniqueness of the architecture of the era (Sisa-Wiebenson 1998).

What we today call History of Architecture is the built manifestation of a variety of factors that have influenced the complex development process of historic buildings. One of these influencing factors is the architectural tendency to exchange construction technology and understanding, which was effective between regions, countries and continents. This extension of the scope of action increased the effectiveness of architecture in history, from regional to national, from the $17^{\text {th }}$ century $\mathrm{CE}$ onwards, even to global expansion. In the framework of the submitted article, the topic cannot be comprehensively and conclusively worked up. Rather, the phenomenon should be addressed and presented for discussion with examples from different periods of a clearly defined geographical area.

In the following, the architectural tendencies of the Carpathian Basin will be examined through case studies in three periods, when the area was under the influence of another Empire, therefore, when the area was in a peripheral situation: in the period of the Roman Empire $\left(1^{\text {st }}-5^{\text {th }}\right.$ centuries CE), the Ottoman Empire $\left(16^{\text {th }}-17^{\text {th }}\right.$ centuries $\mathrm{CE}$ ), and the part of the Austro-Hungarian Monarchy $\left(19^{\text {th }}-20^{\text {th }}\right.$ centuries CE). The aim of the paper is to examine if there are similar or different architectural results from comparable, peripheral situations and external influences. Within this framework, the phenomena of architectural influence is described with a defined terminology.

The use of the phenomenon of the architectural transfer describing processes, interactions and its architectural result is a relevant and actual methodology in the 
contemporary discourse of architectural history. This approach has relevance especially in the light of globalisation: assessing the history of globalisation, its cultural and political impact on overall development. Also, for examining the architectural context of an area under direct influence, thus in the case of the architectural character of colonised territories (Pilsitz 2018). The relevance of the question is clearly expressed by the large number of articles published on the subject (Canizaro 2012; García-Castrillón 2014; Hofman 2013; Moravánszky-Lange 2017).

However, this approach can be observed less in the public consciousness of the Hungarian architectural history literature. Therefore, the aim of the authors is to publish cases and ideas of the architectural history of Hungary for the current international scientific discourse of architectural transfer and export. At the same time, to generate further discourse by introducing the concepts of architectural transfer and architectural export - primarily regarding the architectural history of the territory of Hungary in the case of the periods examined in the article.

\section{DEFINITION OF PERIPHERAL SITUATION IN THE EXAMINED AGES}

In the three examined periods, it can be accepted that the territory of the Carpathian Basin became peripheral under the influence or within the border of an empire with different central territories from a geographical point of view. The term periphery is derived from the ancient Greek term 'periphéro', and originally meant 'to carry around', which unmistakably indicates a type of transport. Also, there is a present discussion on the terminology of periphery in architectural context, which shows the actuality of the topic and the geographical location's influence to the general architectural historiography. (NN 2018. 47-51.)

In the article, the term periphery is used exclusively for the examined case studies, since the geographical area described is not a periphery in other time periods and possibly in other contexts (Matthias Corvinus, 1458-1490). In the particular case, the center is to be understood in the sense of an action-oriented experience (architecture) that has been transferred to another place by periphéro (carrying around). This demonstrates the distance to the starting point. However, the general features of the different peripheral situations of the periods shall be examined in the following paragraphs not only according to the geographical location, but with a more complex approach.

\subsection{THE PERIOD OF THE ROMAN EMPIRE $\left(1^{\mathrm{ST}}-5^{\mathrm{TH}}\right.$ CENTURIES CE)}

Pannonia was one of the provinces on the borderline of the Roman Empire, therefore it was a strategically important area for the defense of the Empire, but at the same time also a transfer area, in which naturally there was commercial and cultural ex- 
change. Several important military and trade routes, such as the Amber Road, passed through its territory. In the early years, only the most demanding developments were carried out related to the defense of its borders. With the beginning of the Romanisation in a gradual way, the process has resulted in the appearance of urban settlements and public buildings. The appearance of the temples of the Capitoline Triad in the forums of the newly founded cities was one of the first signs of Romanisation, as it was a symbol of the sacred presence of Rome.

The area was initially a simple borderline in a both political and geographical way. Despite its singnificance acquired exclusively for strategic reasons, by the end of the $2^{\text {nd }}$ century CE it had grown so radically that Septimius Severus (193-211) came to power with the help of the legions stationed here. This also had a major impact on architecture, since large-scale construction works began throughout Pannonia, making the province an integral part of the empire. Because of the fact that the members of the army settled in Pannonia originated from different areas of the empire, including the border provinces, the influence of the architecture not only of the center but also of other peripheries appeared in the territory.

\subsection{THE PERIOD OF THE OTTOMAN EMPIRE $\left(16^{\mathrm{TH}}-17^{\mathrm{TH}}\right.$ CENTURIES CE)}

The differentiation of the central, semi-peripheral and peripherical territories of the Ottoman Empire, and the situation of the land of Hungary within these groups are absolutely relevant and complex questions. From a geographical point of view, it might be obvious that the palace and its surroundings, therefore the region around Constantinople denotes the absolute central area of the empire, with other cities where prominent imperial investigations were carried out. However, the northern borders of the Balkans, and the Hungarian territories have peripheral status, since Hungary was the north-western border of the Empire. Moreover, the areas of the Carpathian Basin which were under Ottoman occupation suffered from a continuous period of war; consequently, in the absence of a longer peaceful interlude favourable for architectural development, except for military constructions, peripherally, the conflict resulted in a stunted architectural evolution, further exaggerated at the edges of the territory. The scholars agree that the situation of the Hungarian lands was different from the Balkans, where the Ottoman domination was longer, with several peaceful periods, which resulted in a more comprehensive influence of the Ottoman architecture.

It shall be emphasised that the area of the Hungarian Kingdom was a dominant state in the previous centuries, in the position of an absolutely central, great power, with rich and outstanding cultural and architectural wealth. This status coincides with the fact that the territory of Hungary was absolutely in the focus point of the longterm Ottoman interests, in the line of the imperial expansion towards Vienna and Central Europe, which is also an important aspect in the question of the architectur- 
al investments. Therefore, not only the geographical situation, but also the long-time Ottoman plans and the persons of the buildings' founders shall be taken into consideration. Since a significant part of historical Hungary became part of the Ottoman State, the most prominent noble families of the empire, for example the grandees such as the Sokollu, Yahya, and Malkoçoğlu families, had positions in the land. Therefore, besides the peripheral geographical situation in the borderlines or the distance from the imperial palace, the founders of the newly erected buildings had prominent influence in the highest rank of the Ottoman State, which is reflected in the architectural formation of the buildings. The land was in the focus point in the long-term Ottoman interests, and from this point of view, the influence of the central, noble architecture is partially visible. From this point of view, it can be assumed that the Ottoman conquest of the lands could result in the architectural and infrastructural reshaping of land, the change of its architectural features but not the loss of its potential. Consequently, in the Ottoman times the territory of Hungary can be counted as peripheral from the geographical aspect, with a highly more significant potential than an average peripheral borderline.

However, since the territory was the field of continuous battles and confrontations between the side of the Habsburg Empire and Hungarian Kingdom, and the side of the Ottoman Empire, in several years, the formerly prosperous land became a buffer zone, which in some cases resulted in a dual domination of two basically different cultures (Hegyi 1976. 274-277). Consequently, despite some single buildings with high quality, erected by prominent founders, the rich history and the potential of the land, the area could not flourish in the period as a whole system, and from this point of view the land could not break out from peripheral circumstances from the aspect of its general conditions during the Ottoman times as other, central lands could do.

\subsection{THE PERIOD OF THE AUSTRO-HUNGARIAN MONARCHY $\left(19^{\mathrm{TH}}-20^{\mathrm{TH}}\right.$ CENTURIES CE)}

In the case of the breweries in Budapest, the company's objective was to increase production quantitatively and further improve its quality. This could only be achieved using the most modern brewing technology at the time. For this purpose, buildings had to be built that met the requirements of the complex production technology and in some cases even became an indissoluble part of it (kiln, malt house). At the same time, the production facilities with their appearance also had to take on the tasks of representation. This constellation resulted in a complex planning task that required detailed knowledge of the specific manufacturing process and the architecture of industrial buildings. As a result of this very specific requirement profile, a number of engineering offices in Germany specialised in the planning of breweries and malt houses around the turn of the century. The services offered were in demand all over Europe, including Budapest. One of these highly specialised planning offices was Theodor Ganzenmüller's engineering association in Weihenstephan / Bavaria. 


\section{THE QUESTION OF ARCHITECTURAL EXPORT AND ARCHITECTURAL TRANSFER}

The starting point of the question is whether architectural transfer should be distinguished from architectural export in terms of its motivation and its mechanism, or is it merely a variation of the transfer. ${ }^{1}$ Both phenomena have similarities, which is why, in the vast majority of scientific investigations, no strict differentiation of the two terms is made. For example, both the transfer and the export of architecture is a temporally continuous event, which for centuries has been effective, is still in progress today and will continue to influence the overall development of architecture in the future (Moranvánszky-Lange 2017). Thus, the exchange of knowledge and culture at the international level becomes a permanent and fundamental factor through which architecture, as we know it, was able to emerge. At the same time, there are also differences that are discussed. With regard to the practical work of today's planners, both the historical and current architectural transfer is a living part of the contemporary architectural discourse. Precisely for this reason, it is an absolute necessity for architects to acquire intercultural competences and to understand the cultural significance of architectural transfer or export, which goes far beyond the exchange of building technology. As a prerequisite for a factual examination of the subject, the terms architectural transfer and export of architecture are first defined. The following proposed definitions are based on the mechanism of the architectural transfer:

\subsection{ARCHITECTURAL TRANSFER}

Architecture does not arise in an isolated neutral zone but in an existing cultural environment with defined technical and social requirements. Specifically, this means that the complex process of planning and construction is always influenced by the real conditions in a defined time interval in which the building is created. In addition to the specific period of emergence and the existing social context, it is above all the concrete spatial morphology that defines a building (Norberg-Schulz 1982). If a type of building, which is always determined by these three factors, is developed for a defined geographic region in a certain time interval, but then placed in a new situational context, that is, from the original place of origin (intellectual centre) to an alternative location (intellectual periphery), a transformation process is triggered (Weber 2017). Characteristic of this process is that architectural elements and patterns are transformed into new spatial manifestations. The newly created spaces will

\footnotetext{
${ }^{1}$ The authors are aware that there are a variety of types of movement and their motivation in architecture. It is beyond the scale of this article to cover all terms (for example 'circulation'). For this see also: Mack 2002. 8-12. Esra Akcan uses the term architectural translation: "The definition of translation includes any act of changing from one place, position, condition, medium, or language. ... Translation in architecture can be discussed in relation to converting from ... one place to another. ... Naturally, translations in architecture engage both the linguistic and the visual." See: Akcan 2012. 7.
} 
become translocal, multicontextual and possibly hybrid (Bernhardt 2015). Thus, the transfer of architecture becomes a means of transcultural interrelationship.

For an architectural transfer, the following basic prerequisites must be met in addition to the above:

- The origin and destination have developed structures in trade and industry for the practical implementation of planning

- The level of education of engineers and architects at university level is comparable in both countries

- The technical level at the commercial level (construction industry, craft) in both countries does not show insurmountable differences

- The transfer is, by its nature, not a one-way street but rather characterised by mutual exchange of knowledge and experience. If one were to visualise this phenomenon in the sense of Aby Warburg, by means of a world map, a multiplicity of connecting streets and paths of cultural exchange on a global level would result.

- The architectural transfer is based on mutual agreements and without the exercise of coercion, so always voluntarily.

- Architectural transfer generates a mutual intellectual and cultural exchange that goes beyond the exchange of building knowledge. The mutual understanding of each other's culture, in turn, fosters trust and is conciliatory in nature.

\subsection{ARCHITECTURAL EXPORT}

If the basic conditions described above do not exist, then the quality of the interconnectedness does not reach the high level of requirements of a true transfer of architecture. In such a case, it can only start with an export of architecture, which by its very nature is not characterised by equal reciprocity, but only works in one direction. An example would be the buildings of the colonial powers intended to demonstrate power and superiority.

\section{ARCHITECTURAL EXPORT OR MODIFIED EXPORT IN THE TERRITORY OF THE ROMAN EMPIRE: THE SPREAD OF THE ADORATION OF THE MAIN ROMAN GODS IN PANNONIA SUPERIOR}

The Roman Empire was the first entity to exert a decisive influence on the architecture of the Carpathian Basin, as an "exporter". As a colonial power, it aspired to establish its culture in the newly conquered territories. One important element of this 
phenomenon was the spread of worship of their gods throughout the empire. ${ }^{2}$ It is the reason that, similar to the main temple of Capitolium in Rome, a great number of cities built a sanctuary in honour of the Capitoline Triad, indicating that the area was part of the Empire (Hingley 2005. 78). As Hingley emphasises in his book, the most clear examples of the typical Roman cities can be seen in those provincial urban centres which were developing in the late $1^{\text {st }}$ century BC and early $1^{\text {st }}$ century CE (Hingley 2005. 77). This was not different in Pannonia and Dacia Provinces (the Province of the Roman Empire on the territory of Carpathian Basin), where, according to current knowledge, the representative architecture and the planned urban structure appeared as a result of the Roman conquest (Šašel Kos 2010. 218). The indigenous people could only build small and probably wooden-like shrines for their gods at their lodging or at some special place. From the $1^{\text {st }}$ century CE, urban settlements gradually appeared in Pannonia with the Capitoline Triad shrines at their centres. Comparing these with the archetype in Rome gives us an idea of whether other architectural communication took place besides simple architectural exports.

Dacia is one of the latest occupied territories of the Roman Empire and the earliest abandoned Roman province (106 and $271 \mathrm{AD}$ ) and only a specific part of it belongs to the geographical unit discussed in this article. The first and the only capitolium of the province is Colonia Ulpia Traiana known from the forum of Traiana Sarmizegetusa. It was excavated by the team of Ioan Piso between 2007-2011 (Mátyás 2018. 127). The temple may have been built in the $2^{\text {nd }}$ century CE, during the reign of Antoninus Pius (138-161 AD). The podium temple at the western part of Forum Novum was $29.40 \times 18.90 \mathrm{~m}$ in size without access steps, and its height is estimated at around $20 \mathrm{~m}$ based on sculptural fragments and antique proportions. Unfortunately, a few stone materials remained, but it is certain that the hexastyle temple belonged to the single-cell capitolium type (Mátyás 2018. 127-131).

In Pannonia Province, only the Capitoline temples of four settlements are known to date: all of them from Pannonia Superior. ${ }^{3}$ However, the state of these towns is different - and in addition one of the temples was erected at the holy mountain of the town -, the buildings can be compared with each other according to the main characteristics.

\footnotetext{
${ }^{2}$ The Roman gods have been unequivocally brought round by the 'colonisers'. The original inhabitants have tried to insert them in their own belief, in many cases identifying them with their own divinities. This part of the article deliberately deals only with temples built in honor of the main gods of the Roman Empire: Iuppiter, Iuno and Minerva. The article does not intend to be concerned with the sacral buidings of Oriental cults - which were particularly spread on the territory of Pannonia. The reason for this is that these places were built not according to official order of the Empire with the intention of colonisation, but on the private money of soldiers and public officials brought from other territories of the empire.

${ }^{3}$ It is known that the sanctuaries of the Capitoline Triads were built on other areas of Pannonia, e.g. at the civil town of Aquincum. However, appreciable architectural remains have not survived. In the case of Aquincum, it is also known that there was a rising podium temple next to the forum framed on three sides with walls - now most of it is under Szentendrei and Keled Roads - and later it became the sanctuary of the imperial cult. Only the details of the foundation can be seen in the ruined area, and just a piece of the forum boundary wall has been reconstructed at full height (Hajnóczi 1987. 105).
} 
Among the examples, from an architectural perspective, the Capitolium of Aquae Iasae has remained in the best condition; it was a major cultic, economic and therapeutic centre of Pannonia Superior. During the first excavation phase, between 19531982, the territory of the capitolium was examined many times. Consequently, the construction periods of the building complex could be clarified. The ruins, which are visible today, date back to the last constructional phase from the $4^{\text {th }}$ century $\mathrm{CE}$ (Nemeth-Ehrlich-Kušan Špalj 2011. 213-216). On the southern side of the forum, between the sanctuaries erected for Iuno and Minerva, the temple dedicated to Iuppiter was excavated (Rendić-Šegvić 1998. 7). The temple of the Capitoline Triad provided a place for the three gods, invariably in one building with one or three cells. However, in this case, three separate buildings were constructed with only one joint wall, which is the main facade in front of the forum. In Pannonia, it is a unique construction in the Empire, only in Brixia - Brescia, Italy - the presumed capitolium has a similar construction. Parallels can also be found in the temple complexes next to the forum of Nesactium - Vizače/Nezakcij, Croatia -, Baelo Claudia - Bolonia, Spain - and Sufetula - Sbeitla, Tunisia; however, the dedication of these temples cannot be determined unambiguously. According to some research, these temples were constructed for the Capitoline Triad only according to the size, location and the relation of the buildings (Sinobad 2007. 241-242). For example, in the case of Sufetula, the three temples were connected with bridges.

Contrary to the aforementioned cases, there is no doubt (2) that the three buildings of Aquae Iasae were the Capitolium of the city, since a Minerva statue - with larger than life-size dimensions - was excavated in a place relatively close to where the original might have been standing (Gorenc 1983-1984. 106). As can be seen from these examples, in Aquae Iasae, the category of architectural communication cannot be simply defined. Since the temples of the aforementioned settlements were built

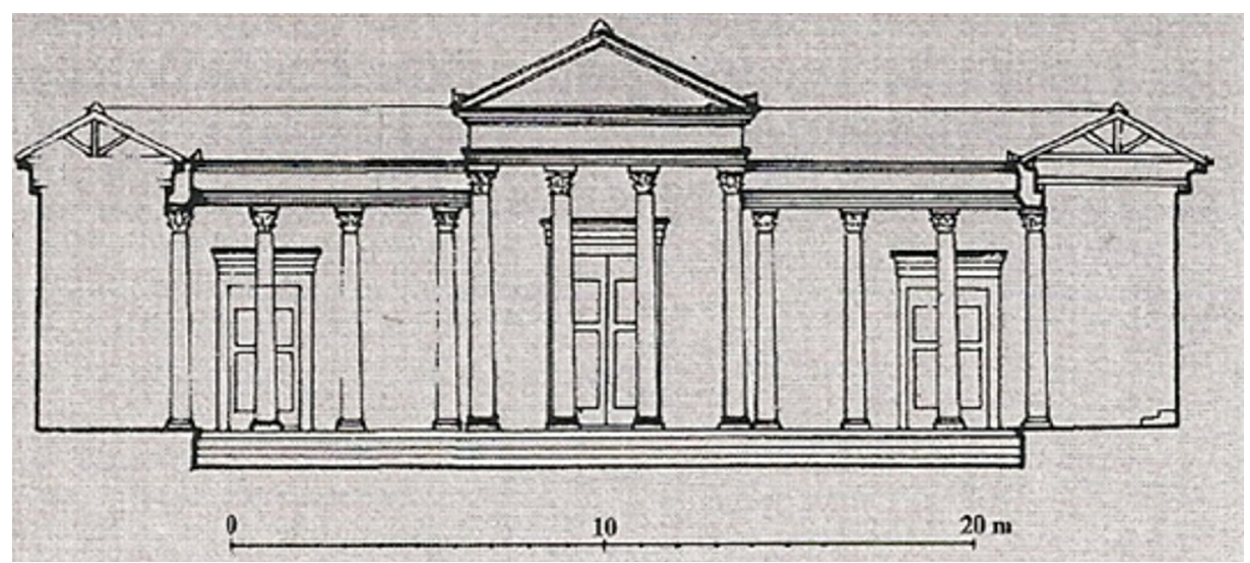

Figure 1. The reconstruction of the Capitolium in Aquae Iasae according to A. Rendić-Miočević. Source: Fitz 1998. 62. 
earlier than the temples of Aquae Iasae, one of them may have been a direct precursor. Since the archetype has already been modified in the city of Pannonia Superior, it can be described as a modified export, irrespective of which reconstructions based on architectural remains are closer to reality. According to one, in front of the three temples, a column-beam porch was located uniformly, and only the part that is in front of the Iuppiter-temple was raised with a pediment (Fig. 1).

Unfortunately, since only one facade drawing was published, it is difficult to determine the spatial relationship of the facades and the mass of the buildings. However, the reconstruction might be incorrect because of the following reasons:

There is no reason for the protrusion of the central part with a tympanum in the plan. Moreover, two columns with different sizes are placed side by side. The other, even more demonstrative reason is that a facade forming, where the column is directly at the axis of the entrance, is inconceivable.

The other reconstruction handles the sanctuaries as three different buildings, namely the height of the facade is defined by the proportion derived from their width, and the wall sections connecting the temples are not stilted until the level of the cornice. The unity of the capitolium was formed by the colonnade at the front (Fig. 2).

The digital model presents the condition of the capitolium during the $2^{\text {nd }}-3^{\text {rd }}$ centuries CE. The supposed visualisation of the $4^{\text {th }}$ century CE conditions had been prepared as a pair. Since the first might be acceptable, the latter is conceivable with difficulty because of the irregularities in its morphology. Two different constructional systems were applied in the antique architecture: column-beam and pillar-arch. Contrarily, the reconstruction represents a column-arch system, which appears only in the architecture of the new age. According to the excavations, the only certainty is that the central sanctuary was rebuilt during the $4^{\text {th }}$ century according to the following: the depth, which was formerly the same as the two buildings on either side, was increased to 9 meters. It was also widened to the Western side on a scale that
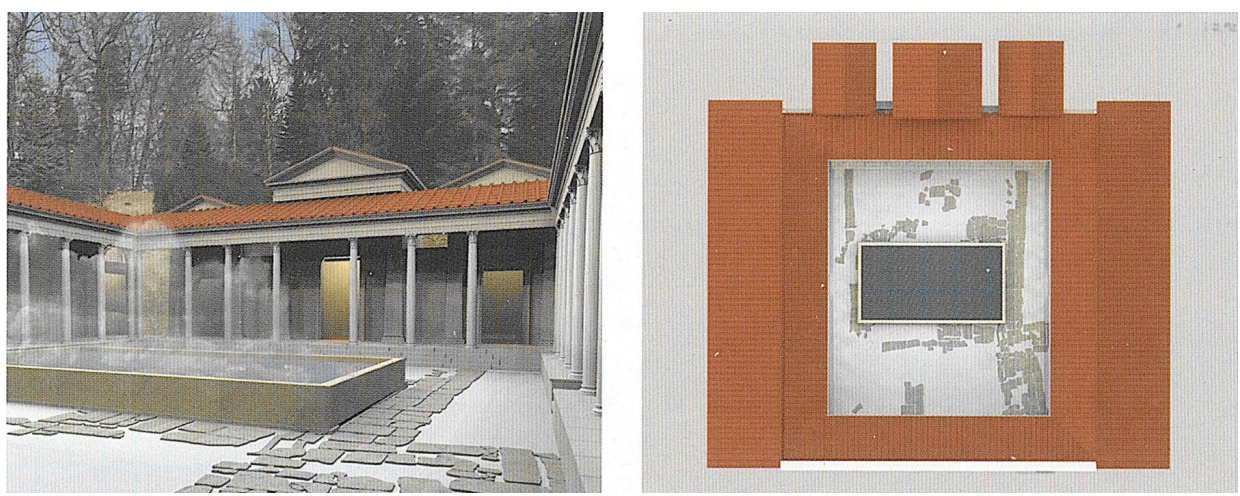

Figure 2. The reconstruction of the Capitolium in Aquae Iasae during the $2^{\text {nd }}-3^{\text {rd }}$ centuries CE, according to D. Kušan Špalj. Source: Nemeth-Ehrlich-Kušan Špalj 2011. 226. (fig. 21) 


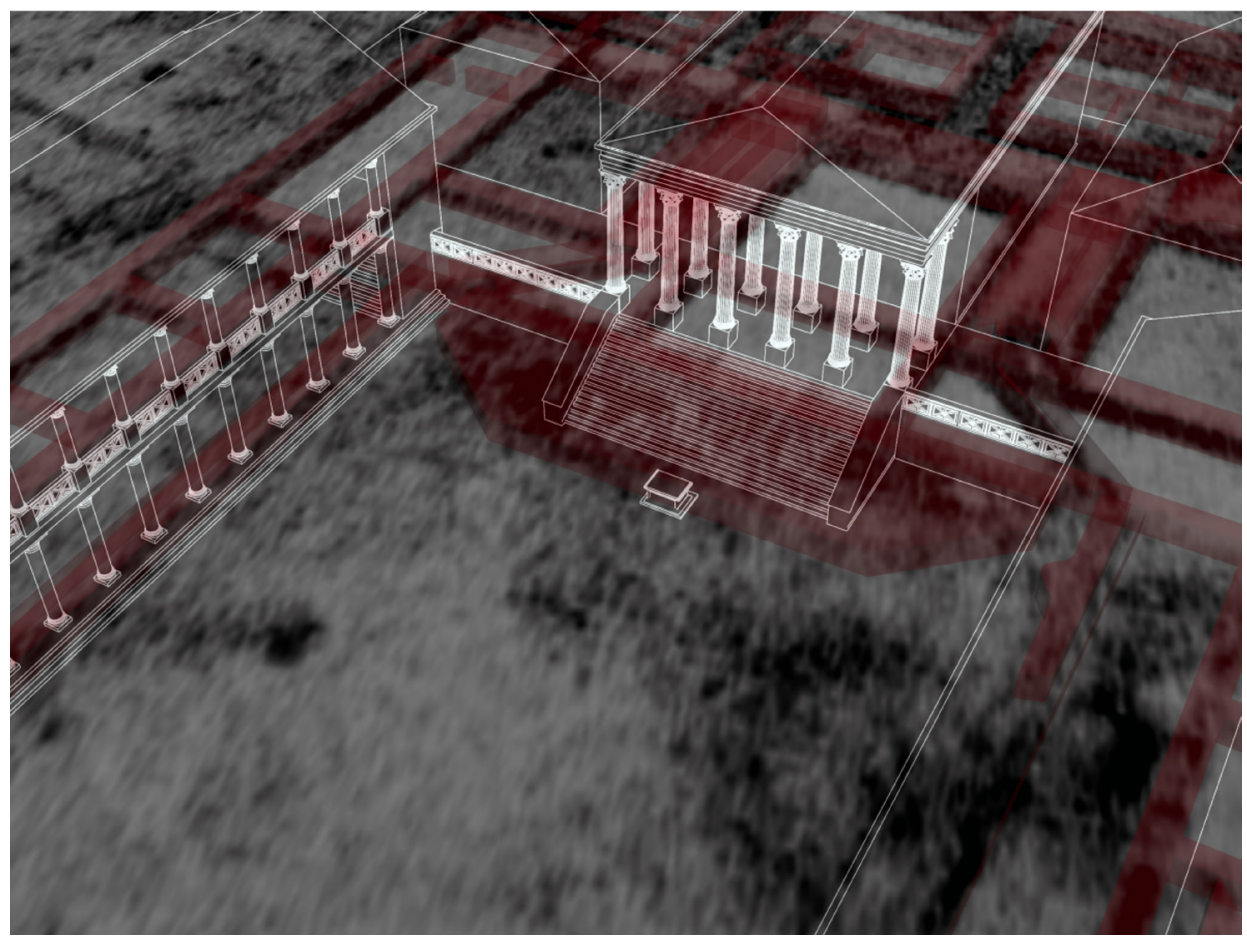

Figure 3. The reconstruction of the Capitolium in Carnuntum.

Source: https://archpro.lbg.ac.at/processing-and-visualisation (accessed 15 September 2020)

resulted in the new surrounding wall partially becoming the eastern side of the western sanctuary. In the $4^{\text {th }}$ century CE, the central temple covered a $9 \times 7$ meter space; the two side temples were $5 \times 4$ meters (Sinobad 2007. 252).

At the centre of Pannonia Superior, in Carnuntum, the temple erected for the adoration of Iuppiter, Iuno and Minerva was placed at the end of the longitudinal axis of the forum of the civil settlement. The survey of the Carnuntum forum began in 1996. The area was surveyed with geoelectric methods, magnetometer and soil radar; (3) however, a full archaeological investigation is still yet to be made.

As a summary of the natural science surveys, the colleagues of Technische Universität Wien (Institut für Architekturwissenschaften - digital architecture and planning) and the Ludwig Boltzmann Institute reconstructed the capitolium of the civil settlement as a hexastylos podium temple without any archaeological evidence (Fig. 3). However, it is almost certain that it was built on the example of Rome; therefore, it represents a contemporary example of architectural export.

In Carnuntum, one other capitolium existed in the Pfaffenberg - Sacer Mons Karnuntinus -, the holy mountain of the settlement, which was denominated during Antiquity as mons Iovis or mons Karnuntinus (Jobst 2006. 37). It became clear that 
besides Iuppiter, the adoration of the Emperor became god also had significance (Jobst 2006. 61). In Pfaffenberg, three temples were built:

Temple I: For the adoration of Iuppiter and the Emperor.

Temple II: For the adoration of the Capitoline Triad

Temple III: For the adoration of Iuppiter

The three temples were excavated by M. Groller in 1898, then in 1935 by E. Swoboda; in 1968, H. Vetters clarified the plotting of the sanctuary district.

The Temple II - the capitolium - became the centre of the composition and the biggest sacral building, a unique temple in both its arrangement and appearance. This might have been constructed during the leadership of Septimius Severus (193-211 CE).

In front of the cella, with $13.45 \times 10.40 \mathrm{~m}$ plan, a $3.50 \mathrm{~m}$ wide and $19.00 \mathrm{~m}$ long porticus existed with four columns. To the cella, a smaller $2.90 \times 2.85 \mathrm{~m}$ to the north and a larger, $4.40 \times 7.45 \mathrm{~m}$ room with a reach from outside are attached (Jobst 2006 . 56-59) (Fig. 4).

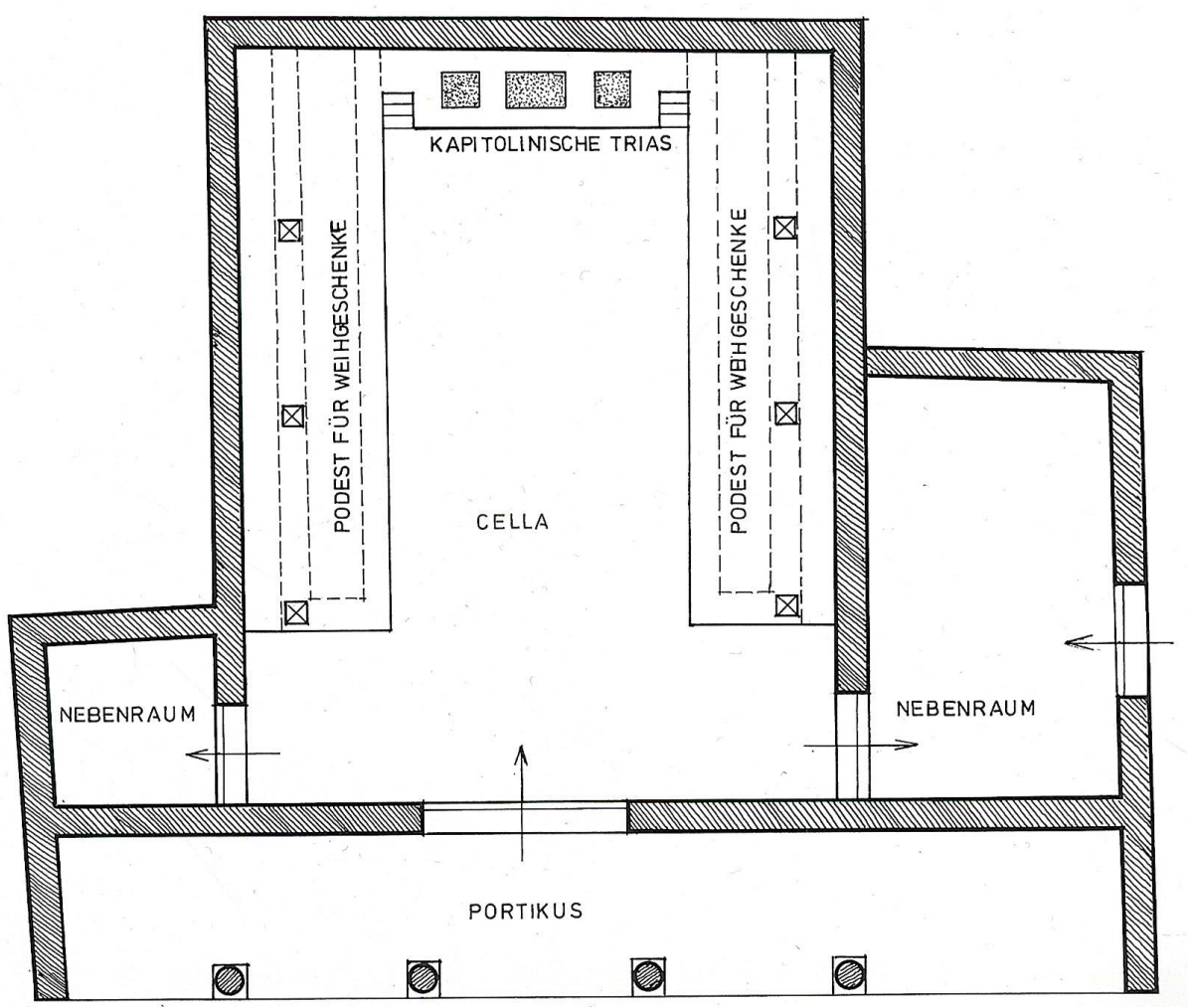

Figure 4. The reconstruction of the Temple II - Capitolium - in Carnuntum, Pfaffenberg. Source: Jobst 2006. 57. (fig. 92) 
The cella is completely symmetric in its arrangement. On two sides, a one-one podium was constructed for the votive offerings; at the sanctuary, according to the reconstruction of $\mathrm{H}$. Thür, on a four-step high podium, the statues of Iuppiter, Iuno and Minerva, sitting on thrones constructed from the lime-sand stone of Leitha, were placed.

The uniqueness of the capitolium of Pfaffenberg is that its cella and the unit formed by four columns in front of it represent the facade scales of the Vitruvian araeostylos - araiostylos or Areostylos - temple (Vitruvius III. 3.10). ${ }^{4}$ The two-sided room is extraneous to the composition, especially because in both its width and length they differ. Considering that the example located in the city of Rome is more monumental, it is conceivable that the longer main facade was constructed with the aim of the visible monumentality. Therefore, the export is not pure in this case: the archetype has been altered locally for the sake of visual impact or perhaps for other reasons; maybe because the original inhabitants have tried to insert the Roman gods into their own beliefs, in many cases, identifying them with their divinities; therefore, in this case, a similar phenomenon occurs.

In Pannonia Superior, the capitolium of two main cities - Scarbantia and Savaria are also known. Their existence was verified by András Alföldi in 1920 according to marble statue fragments (Alföldi 1920-22. 12).

The exact place, an arrangement of the forum of Scarbantia has been known only since the beginning of the 1980s; however, the remains of the temples of Capitoline Triad were found approximately a hundred years before, in the winter of 1893-1894, during the construction of the City Hall. The fragments of the three main gods' marble statues appeared at that time (Szakál 1965. 37) (Fig. 5). The plan excavation on the forum could only start in 1965 when E. Szakál circumscribed the temple of Capitoline Triad according to the details and description of L. Bella. This made possible the setting of the precise location of the capitolium (Póczy-Czeglédy 1967. 223).

In Savaria, besides the statue fragments, only a part of a marble geison, an aedicula wall of large size and some monolithic granite columns (two of them are in Ják, the others are in the front of Szombathely Museum ) remained from the building erected for the Capitoline Triad (Paulovics 1940. 20). From these, only an approximate size can be deduced, although its architectural quality is perceptible. Construction of the temple is presumed to have begun in $82 \mathrm{CE}$, the same time as the renovation of the Roman capitolium. It is conceivable that the capitolium of Savaria might have been similar to the one renovated in Rome as the composition of the Capitoline Triad in Szombathely closely follows it (Kádár-Balla 1958. 10-12).

The Capitolium in Aquae Iasae and Temple II Pfaffenberg are good examples of modified architectural export as the archetype was not the "original" or it was mod-

\footnotetext{
${ }^{4}$ However, this is a rare temple type, we know some examples e.g. temple B at Pyrgi 510 ca. BC (Colonna 2006. 155).
} 




Figure 5. The view of the reconstruction of the forum of Scarbantia from the south. Source: Sedlmayr 1994. 86. (Fig. 3)

ified and adapted to the local conditions. The quality of local knowledge and workers might have played a major role in the appearance of modified architectural export. ${ }^{5}$

However, the Capitolium in Carnuntum and Scarbantia - and probably in the case of Savaria - are almost replicas of the main temple in the city of Rome. These cases are good examples that illustrate architectural export rather than transfer.

5 The similar phenomena can be examined in other areas of the Roman Empire. From the $19^{\text {th }}$ century, Roman architecture in the north-western provinces was generally seen as the result of copying new concepts from the city of Rome itself. However, there is a more wide diversity, which is seen as the product of an intended transformation based as well on local capabilities as requirements (Lipps 2017). 


\section{THE TERRITORY OF THE CARPATHIAN BASIN UNDER OTTOMAN RULE: ARCHITECTURAL EXPORT AND MODIFIED ARCHITECTURAL EXPORT}

The central territory of the Carpathian Basin was under the rule of the Ottoman Empire during the $16^{\text {th }}$ and $17^{\text {th }}$ centuries. Despite the long Ottoman dominion, remarkably few Ottoman buildings can be identified in Hungary, as many were demolished, collapsed or converted after the $17^{\text {th }}$ century, preserving mainly the baroque layers of the past (Baku-Kovács 2018. 425-448). The number of newly erected buildings during the Ottoman era was limited; the conversion or re-use of the extant building fabric was also typical (Sudár 2018. 381-406). Therefore, the buildings can be grouped according to function and whether they were newly erected by the Ottomans or converted from an existing building.

In a system that was strictly centralised, and thereby the architecture was also superintended by the Palace (Barkey 2008; Günay 2016. 186; Rabb 2013), it is a relevant question as to what happens in an area which is within the boundaries. Consequently, examining the primary direction of architectural influence, in the case of the Ottoman buildings in the territory of Hungary, the direct connection between the Imperial centre and the centre of the vilayet seems to be obvious.

The occupation of a territory was followed by the establishment of a djami, where the first, Friday praying could be held. During prayers, the hutbe would be recited, when the name of the actual emperor was proclaimed as a sign of the domination. Since these buildings necessarily had to be arranged in a short time, mainly extant buildings were quickly converted to be able to accept the ceremony, and express the act of the occupation (Sudár 2018. 381-406). Consequently, the djamis founded by the padishah in the territory of Hungary were mainly former Christian churches converted into Muslim prayer buildings. The key question is whether there are any visible architectural features that refer to a direct connection with the Imperial capital or any other territories of the Empire related to the aspect of the founder? In the case of the churches converted to djamis, there is limited evidence of the former Ottoman function. Consequently, in the case of the converted buildings by order of the emperor, there is a direct architectural export between the imperial centre and the peripheral territory (different regions of Hungary).

Besides these Imperial constructions, the founders can be individuals - mainly noble families (ocak) - as charitable endowments (waqf). During the classical period of the Ottoman Empire, the architecture played an obvious and important role for the transmission of a readily accessible Ottoman identity, which constituted an ideal for the members of the Ottoman ruling elite. The state officials were incorporated into the Ottoman archetypes, and artistic canons developed at the court; in this way, the provincial elite transported and spread the imperial image to the peripheral centres to legitimise the Ottoman rule. In the case of Hungary, this architectural export was not directly from the centre as many of the noble families who participated in the conquest of Hungary were derived from Bosnia; the territory of Bosnia played a 
mediating role with the Ottoman Balkans. This connection can be seen in both architectural details (windows, niches, gate motifs and mihrabs) and the general space formation as a result of the noble architectural patronage since the Ottoman ruling elite had origins from the Balkans - the area of Rumelia (Artan 2006. 85, 100). According to the space typology of Győző Gerö, two main archetypes can be identified - the square plan with single dome and the rectangular plan covered with a gabled roof (Horváth-Zsembery 2008), with parallels to Bosnian examples. Therefore, according to Gerö's research, Ottoman architecture in Hungary is the extension of Balkan Ottoman architecture, with its unique characteristics (Gerö 2003. 181184). The specific type of the single-spaced mosque with a hemispherical dome, a steep minaret, and a portico with three or five bays was the result of a centralised privilege of the Sultan to spread his policy on faith and centralised sovereignty (Hartmuth 2010. 25). Consequently, in the case of most buildings that were erected by individuals or influential nobles of significant dynasties, there is a direct architectural export between a semi-peripheral territory (the Balkans) and the peripheral territory (different regions of Hungary), with a strong imperial architectural claim - with or without some modifications - and most of the newly erected buildings can be placed in this group.

In some cases, the founders, who were members of families with influential connections directly to the Ottoman capital, influenced the architecture. Sokollu Mustafa Pasha, the beylerbeyi of Buda, was the cousin of Sokollu Mehmed Pasha, the Grand Vizier between 1565-1579. This may be reflected in the architecture, since the rare plans of the two baths built by the Pasha show similarity with Sokollu Mehmed Pasha's bath in Istanbul, Azapkapı is also called Yeşil Direkli Hamam; in both cases, the dome is supported by columns. Therefore, the building of Sokollu Mustafa Pasha has a strong connection with the central architecture with some local variance (Papp 2013. 577-578). From this point of view, similar tendencies can be observed as in other, peripheral areas of the Empire (Özgüven 2004; Boqvist 2010). Hence, in the case when the founder has familiarity with the conditions of the capital and connections are significant, the architectural export between the centre and periphery is direct, with partial local variance.

As a case study of the period, the research can be limited to one specific building type, which is the türbe (shrines erected for emperors, nobles or honoured persons). The memorial (makam) türbe of Sultan Suleiman the Magnificent was located in the surroundings of Szigetvár. It was a square planned building, similar to the makam türbe of Sultan Murad in Kosovo (Şenyurt 2012), with a single dome and a foreroof divided into three parts. The excavated palmette motive is equal to those found on the türbe of Suleiman in Istanbul (Hancz 2017.97-101). This motif is connected with Sultan Suleiman himself and can be found in different miniatures related to the sultan (Özdengiz Başak-Peker 2017. 147). Therefore, in this case, when the building was dedicated to the memory of the Emperor, we can observe direct architectural export of the official architecture from the Ottoman capital. 




Figure 6. The türbe of Gül Baba in Buda. (Photograph: Authors, 2019)

Within Hungary, two other türbes can be found in good condition: the türbe of Gül Baba in Buda (Fig. 6) and the türbe of Idris Baba in Pécs (Fig. 7). Both buildings have an octagonal plan covered with a dome, which is typical of the türbes constructed in the $15^{\text {th }}-16^{\text {th }}$ centuries not only in the Balkans but also in Anatolia. After the reoccupation of the territory of Hungary, both buildings suffered many modifications to their building structure during the conversion to public functions or Christian chapels.

The main difference between the two türbes is in the material of their walls since the türbe of Idris Baba was constructed with irregular quarry stones of lesser value and the dome was covered with ceramics, which represent closer relations to the Balkans. However, the türbe of Gül Baba has one more uniqueness: it has only one window on the side of Buda. From this point of view, in the following paragraph it can be seen how strictly regulated the Ottoman architecture was, and why both buildings have similar features.

However, since the türbe of Gül Baba has one window, it is a unique feature among all the Ottoman shrines. Therefore, it is an example where the architectural relation- 


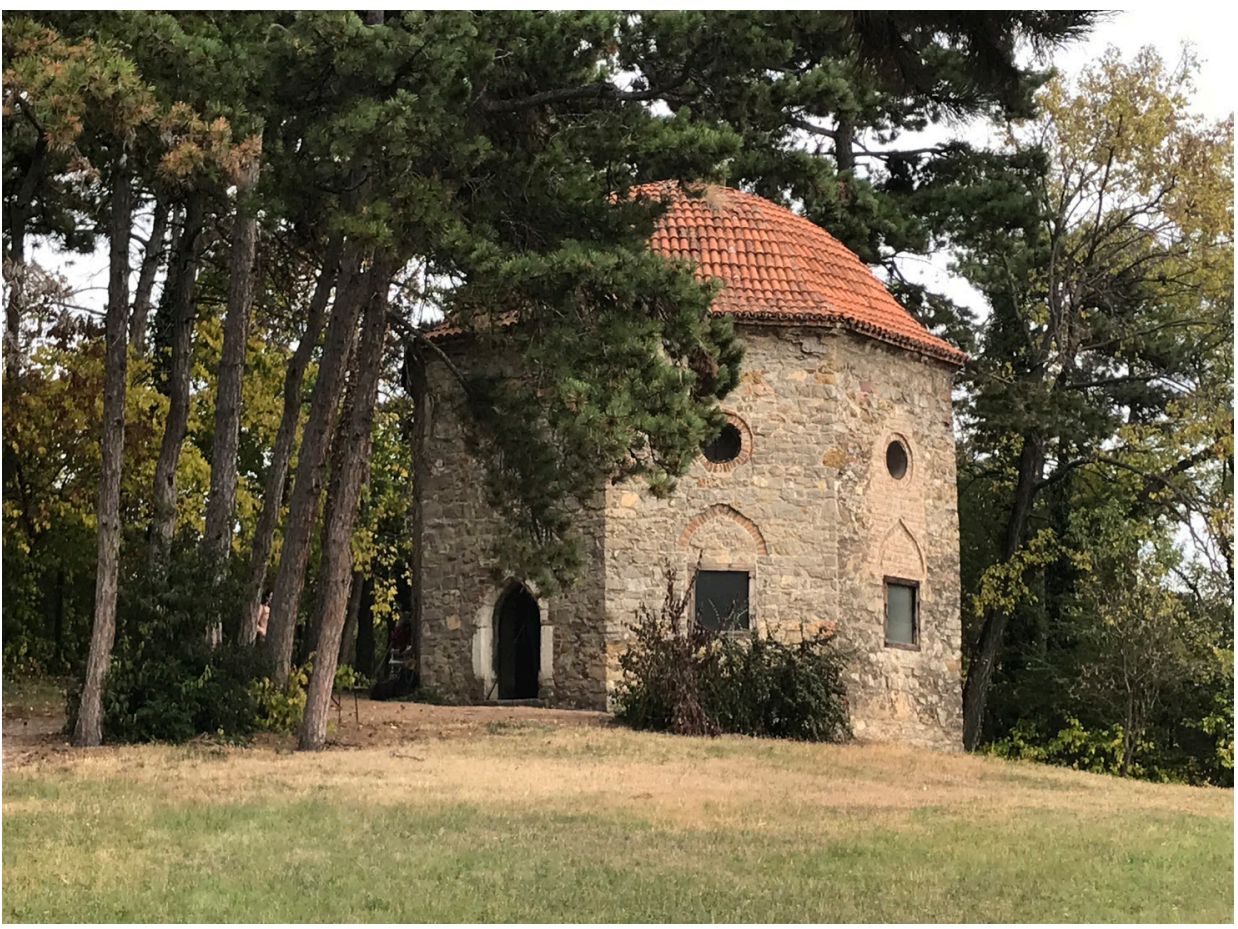

Figure 7. The türbe of Idris Baba in Pécs. (Photograph: Authors, 2018)

ship between the centre and periphery are direct, with partial local variance. Moreover, in contrast to the previous examples, when the phenomena of architectural export could be observed, it is an example of modified architectural export and not the case of architectural transfer.

\section{HISTORICAL INDUSTRIAL ARCHITECTURE: ARCHITECTURAL TRANSFER IN THE ERA OF THE AUSTRO-HUNGARIAN EMPIRE}

The transfer of architecture is particularly pronounced in historical industrial buildings as a factor of the building design. Especially after the onset of the Industrial Revolution, the intensity of the transfer of industrial architecture increased parallel to technology and knowledge transfer. From the middle of the $18^{\text {th }}$ century, the Industrial Revolution was in full swing in Britain. The enormous economic boom had several reasons but was mainly technologically determined. The production in- 
creases were huge, and the European market was flooded with good quality and cheap goods.

As a consequence of this development, special types of construction had been developed in England in order to optimally set up the machines. Depending on the industry, for example, factories were built as multi-storey buildings for weaving mills or large-scale hall buildings for iron foundries and mechanical engineering (Pilsitz 2013). By contrast, economic and technological development on the European continent had practically come to a halt at the beginning of the $19^{\text {th }}$ century. Due to the Napoleonic wars, the conditions for a trouble-free development were not given, which is why it could barely compete with England. There was a great need to catch up with modern production technology and buildings suitable for the specific needs of the industry. One way to understand the English economic miracle was to recruit British professionals (so-called machinists) and learn from these professionals. Another way to acquire know-how was to undertake a study trip to England to see the industrial plants and structures. In reality, it was a form of industrial espionage (Roth 1976). A well-documented example of such a "study trip" is the five-month field trip undertaken by Karl Friedrich Schinkel and Wilhelm Beuth (Commissioner of the Prussian Government for the Advancement of Industrial Development) to England in 1826. The order for this enterprise was granted by the King of Prussia, Friedrich Wilhelm III. The purpose of the extended journey was, among other things, to study industrial production methods and the extensive use of iron; Schinkel mainly visited factory buildings and civil engineering works. The technical and construction facilities were documented in detail in the form of sketches, drawings and written records.

Above all, the typical construction method for English industrial buildings (flat vaulted caps on iron columns) and the possible widths, interrupted only by columns spaces, influenced Schinkel's sustainable approach to design. When planning the Bauakademie on the Werdersche Markt in Berlin (1831) and the Public Royal Library (1835, not realised), these structural elements were used indoors. In the same way, elements of the facade design, such as the exposed brickwork, the large glass windows, high-opening pilaster strips and arched forms in Schinkel's designs, can be traced back to the influence of English industrial buildings. Additionally, many smaller building details made of iron, such as canopies and stairs, can be attributed directly to role models that Schinkel saw on his trip to England (Eisen 2018). Overall, it can be stated that Schinkel's buildings are influenced by constructional elements with which he was confronted during his trip to England. These were further developed by him into innovative forms and design elements in a new functional context. Thus, Schinkel does not transfer buildings from England to Prussia, but rather individual components and planning principles. 


\subsection{BREWING HOUSE OF THE FIRST HUNGARIAN STOCK BREWERY IN BUDAPEST}

A noteworthy example of a historical architectural transfer in industrial construction is the brewhouse of the First Hungarian Stock Brewery (Hungarian: Első Magyar Részvény Serfőzde Rt.), built in 1908/1909 in the Budapest district of Kőbánya. The office Theodor Ganzenmüller (production technology) and Franz Rank (architecture) from Weihenstephan / Bavaria / Germany were commissioned to plan the architecture and production technology. The brewery was the first jointly planned construction project that was also realised structurally. The entire complex includes a brewery, a maturing cellar and a bottling hall. For load transfer, a reinforced concrete structure is used, which means that traditional methods of construction in the brewing industry in Central Eastern Europe, such as Prussian cap vaulting for ceilings, had finally been overcome. Only with the introduction of the new building material and construction method was the installation of the then most modern production technology to be realised. In addition to the increased fire protection, the greater static load capacity of ceilings and walls was crucial in terms of load transfer and vibration. For example, large capacity brewing vessels could now be installed that could reach construction heights over several storeys. The production could now be arranged in superimposed spaces, resulting in a vertical workflow from top to bottom using gravity. With regard to spatial development in breweries, vertical intersections formed over several storeys, between which the technical installations were the connecting elements.

The facade of the building was designed in the style of Neo-Baroque palace architecture and thus formed a clear contrast to the future-oriented building construction (Fig. 8). However, the combination of contemporary construction and historicizing exterior design is not arbitrary but arises from a creative attitude of the planner. From 1900, Rank's architecture is characterised by the search for a Bavarian "home-style". In doing so, he subordinates his architecture to the built environment and, when designing the facade, prefers to quote from the baroque wealth of forms (Hirsch 2000). When considering the historical continuity, he tries to create an authentic architecture whose roots are ultimately in German Romanticism (Gamm 1997). Yet this emphasis on the regional in Rank's architecture, as an expression of the search for identity and cultural difference, is not to be equated with the rejection of the stranger, but rather as an invitation to the meaningful classification of a building in the original context, in the sense of the genius loci (landscape, history, climate, attitudes of the inhabitants). However, with the architectural transfer of the brewery building of the First Hungarian Stock Brewery from Bavaria to Budapest, this principle is reversed in an opposite case. Although Ganzenmüller and Rank were entrusted with the planning for the production technology and buildings, the project implementation in BudapestKöbánya, however, was carried out by Hungarian architects and engineers. When constructing the project in Budapest, Dezső Hültl, István Puscher and Emil Schimanek influenced the final design and functionality with their technical knowledge. It can 


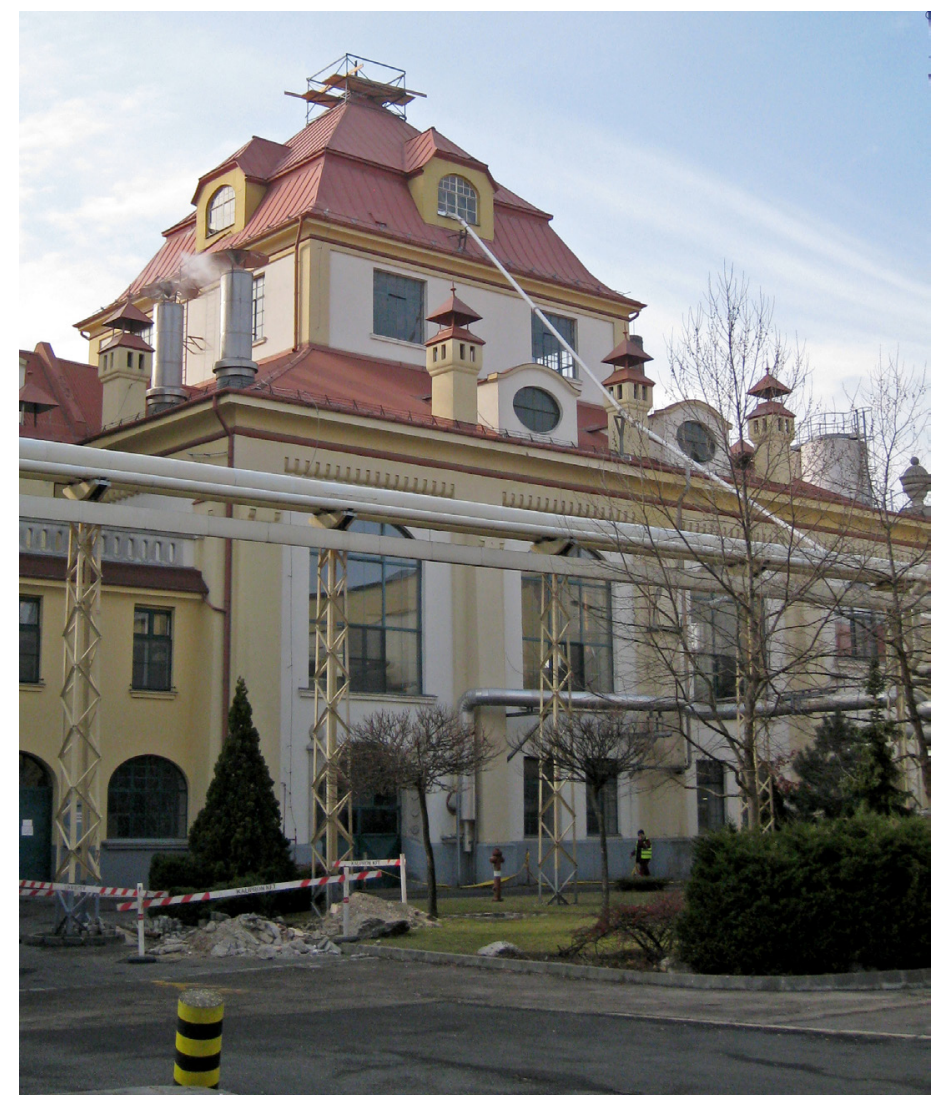

Figure 8. First Hungarian Stock Brewery. Facade. Budapest, Hungary. 1909. (Photograph: Authors, 2015)

be assumed that the experiences and insights gained during the realisation of the project were also incorporated into the subsequent brewery buildings of the planning office Ganzenmüller and Rank in Bavaria. A notable example of this is the Ernst von Moy'sche Hofbräuhaus (built in 1912) in Freising (Germany) (Fig. 9).

Thus, this project is a true architectural transfer, which, by its nature, is not a oneway street, but rather a mutual exchange of knowledge and experience. This cooperation between the German and Hungarian engineers gives an indication of the basic requirements for a transfer of architecture and technology: The starting point and destination (Region-City, here Bavaria-Budapest) have similarly developed structures in trade and industry for the practical implementation of the planning. Another factor is a comparable level of education of engineers and architects in higher education, and skilled workers at the commercial level in both countries for the networked and qualitative construction and possibly planning process (Pilsitz 2015). 


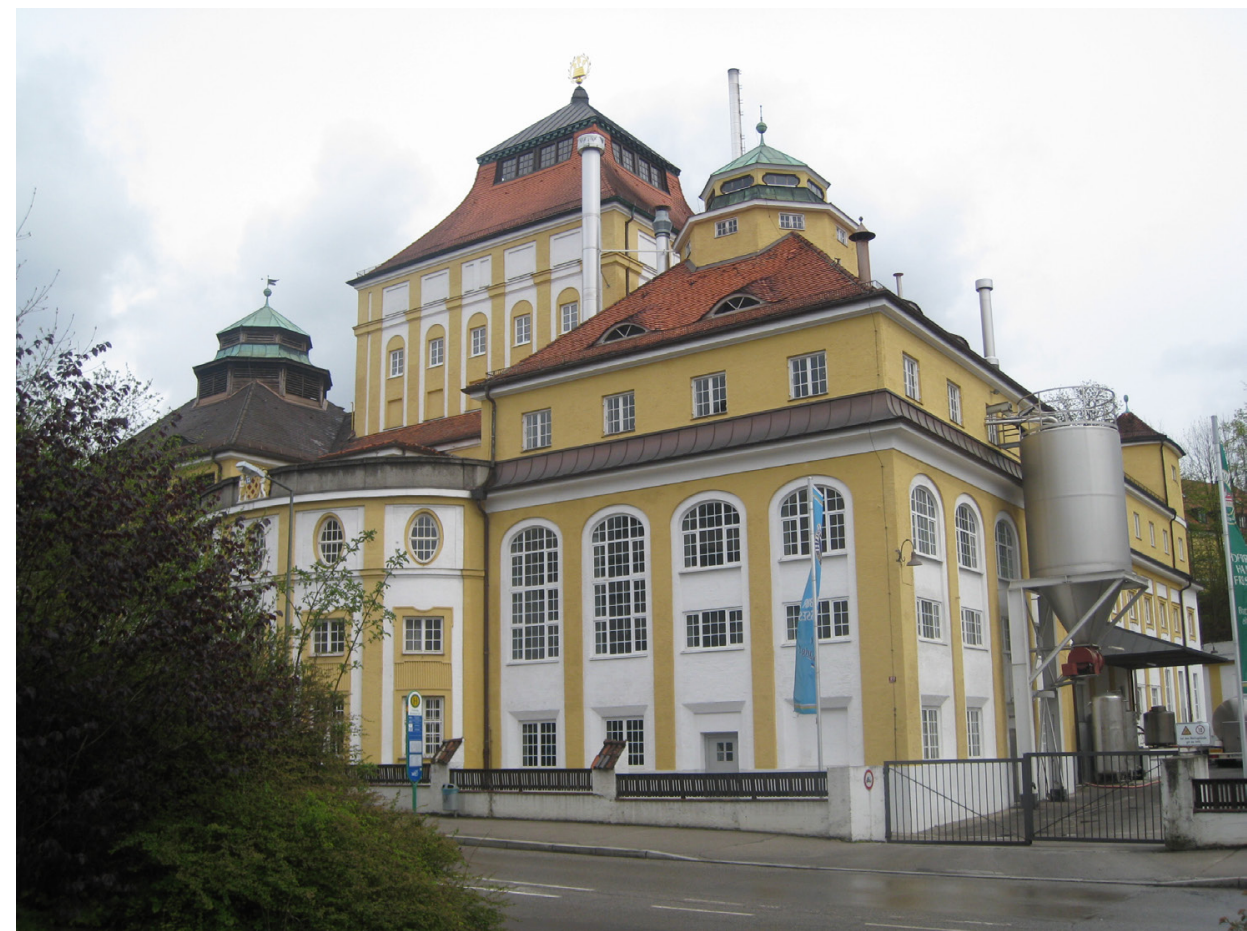

Figure 9. Brewhouse Freising. Facade. Freising, Germany. 1912. (Photograph: Authors, 2015)

\section{CONCLUSION - DIFFERENCES AND PARALLEL TENDENCIES BETWEEN THE RESEARCHED PERIODS}

The phenomena of architectural transfer has been a factor that has influenced the history of architecture. However, this paper recommends drawing a distinction between the terminology of architectural transfer and architectural export as different dispositions of the aspect of knowledge transfer.

In the paper, the architecture of different building types of three periods of a defined territory - the Carpathian Basin - were examined according to this aspect. The purpose was to define and describe some features and characteristics of the phenomena of architectural transfer and export according to case studies. The three different periods, the Roman places of worship $\left(1^{\text {st }}-5^{\text {th }}\right.$ centuries CE $)$, the Ottoman architecture $\left(16^{\text {th }}-17^{\text {th }}\right.$ centuries $\left.C E\right)$, and historic industrial buildings of the $19^{\text {th }}-20^{\text {th }}$ centuries $\mathrm{CE}$ were selected because the area was under the influence of a foreign state and foreign architectural context. 
Architectural export and transfer are both perceptible during the examined contexts; however, the degree varies. Moreover, there is a difference between the impetus that generated the architectural export or transfer. In the case of Pannonia, only exports and modified exports can be observed. The reason is probably that the indigenous population had not developed representative stone-constructed antecedents as existed in Rome and several other territories of the Empire. For this reason, there were no "qualified" architects among them, so the knowledge transport was only possible in one direction. Being a frontier, the architects were military-originated, so it is possible that Aquae Iasae and Sufetula Capitol are similar constructions.

In the Ottoman period, the demand for the buildings in the case studies was created by an Empire with a different cultural environment; therefore, the created building represented a unique building type with no predecessors in the Carpathian Basin. The result was that, by the end of the Ottoman period, both the function and the architectural features were changed. Consequently, in this case, architectural transfer cannot be detected, only architectural export, which has one direction: from the imperial centre to the Carpathian Basin - in some cases, with the transition of the Balkans. There is, characteristically, a direct architectural export between the imperial centre and the peripheral territory, with local variances; however, in some individual examples, the character of the architectural transfer can be observed.

In the examined industrial building, there has been an exchange of knowledge about construction technology and architecture. However, this represents a specific individual case, which cannot readily be transferred to the development of industrial architecture in general.

Although the architectural-historical examples are the most representative cases from when the Carpathian Basin was in a peripheral situation, the authors' aim is to inspire colleagues to examine further case studies in different areas and periods to generate further discussion and dialogue on this important aspect of the architectural history.

\section{REFERENCES}

Akcan, Esra: Architecture in Translation. Germany, Turkey and the Modern House. Duke University Press, Durham and London 2012.

Alföldi, András: Kapitóliumok Pannoniában [Capitolines in Pannonia]. Archaeologiai Értesitö 39 (1920-1922) 12-14.

Artan, Tülay: Questions of Ottoman Identity and Architectural History. In: Arnold, Dana - Altan Ergut, Elvan -Turan Özkaya, Belgin (eds.): Rethinking Architectural Historiography. Routledge, London and New York 2006. 85-109.

Baku, Eszter - Kovács, Máté Gergő: A kulturális emlékezet rétegei. Oszmán épületek emlékezete Magyarországon [The Layers of Cultural Memory. The Memory of Ottoman Buildings in Hungary]. In: Ittzés Gábor (eds.): Viszály és együttélés. Vallások és felekezetek a török hódoltság korában [Strife and Coexistence. Religions and Religious Denominations in Hungary in the Age of Ottoman Rule]. Universitas, Budapest 2018. 425-448. 
Barkey, Karen: Empire of Difference. The Ottomans in Comparative Perspective. Cambridge University Press, Cambridge 2008.

Bernhardt, Anne-Julchen - Weber, Anna - Röver, Bruno: Transfer - Bauten von Migranten in der Bundesrepublik [Transfer - Buildings of Migrants in the Federal Republic]. http://arch.rwthaachen.de/cms/Architektur/Forschung/Verbundforschung/Context-and-Form/Projekte/ Forschungsprojekte/ hzqq/Tansfer-Bauten-von-Migranten-in-der-Bundesrepublik Deuschland (accessed 5 February 2019)

Boqvist, Marianne: Centre and "Periphery" in the Syrian Countryside: the Architecture of Mosques in Governmental Foundation on the Ottoman Imperial Roads. In: Hartmuth, Maximilian (ed.): Proceedings of the International Conference 'Centers and Peripheries in Ottoman Architecture. Rediscovering a Balkan Heritage'. CHwB, Sarajevo 2011. 60-79.

Canizaro, Vincent B. (ed.): Architectural Regionalism. Collected Writings on Place, Identity, Modernity, and Tradition. Chronicle Books, San Francisco 2012.

Colonna, Giovanni: Sacred Architecture and the Religion of the Etruscans. In: Thomson de Grummond, Nancy - Simon, Erika (eds.): The Religion of the Etruscans. University of Texas Press, Austin 2006. 132-168.

Eisen, Markus: Englandreise, 1826 [England Travel, 1826] http://www.karlfriedrichschinkel.de/leben/ englandreise.html (accessed 5 February 2019)

Gamm, Gerhard: Der Deutsche Idealismus - Eine Einführung in die Philosophie von Fichte, Hegel und Schelling [German Idealism - An Introduction to the Philosophy of Fichte, Hegel and Schelling]. Reclam Verlag, Leipzig 1997.

García, Francisco Prado - Castrillón, Renato D’Alençon: Eingewanderte Baumeister. Architekturtransfer zwischen Deutschland und Chile. DOM, Berlin 2014.

Gerö, Győző: Balkan Influences in the Mosque Architecture of Hungary. In: Gerelyes, Ibolya - Kovács, Gyöngyi (eds.): Archaeology of the Ottoman Period in Hungary. Hungarian National Museum, Budapest 2003. 181-184.

Gorenc, Marcel: Minerva iz Varaždinskih Toplica [Minerva from Varaždinskih Toplica]. Vjesnik Arheoloskog muzeja u Zagrebu 3 (1983-1984) 16-17. 95-108.

Günay, Reha: Sinan. The Architect and His Works. Yem, Istanbul 2016.

Hajnóczi, J. Gyula: Pannónia római romjai [Roman Traces of Pannonia]. Müszaki Kiadó, Budapest 1987.

Hancz, Erika: Nagy Szulejmán Szultán szigetvári türbe-palánkjának régészeti feltárása (2015-2016) [The Excavation of the Türbe-Palisade of Sultan Suleiman the Magnificent in Szigetvár (20152016)]. In: Pap, Norbert - Fodor, Pál (eds.): Szulejmán Szultán Szigetváron. A szigetvári kutatások 2013-2016 között [Sultan Suleiman in Szigetvár. The Researches in Szigetvár between 20132016]. Hungarian Academy of Sciences - University of Pécs, Pécs 2017. 89-130.

Hartmuth, Maximilian: The History of Centre-Periphery Relations as a History of Style in Ottoman Provincial Architecture. In: Hartmuth, Maximilian (ed.): Proceedings of the International Conference 'Centers and Peripheries in Ottoman Architecture: Rediscovering a Balkan Heritage'. CHwB, Sarajevo 2011. 18-29.

Hegyi, Klára: Egy világbirodalom végvidékén [On the Border-land of a World Empire]. Gondolat, Budapest 1976.

Hingley, Richard: Globalizing Roman Culture: Unity, Diversity and Empire. Routledge, London and New York 2005.

Hirsch, Stefan: Heimatstil. In: Mair, Karl (ed.): Zwischen Aufbruch und Moderne. Rosenheimer, Rosenheim 2000.

Hofman, Michael: Deutsche Kolonialarchitektur und Siedlungen in Afrika. Imfhof, Petersberg 2013.

Horváth, István - Zsembery, Ákos: Az esztergomi Özicseli Hadzsi Ibrahim-dzsámi kutatása és mủemléki bemutatása [The Research and Architectural Conservation of the Medieval Özicseli Hadzsi Ibrahim Mosque in Esztergom]. Épités - Épitészettudomány 36 (2008) 1-2. 3-41. 
Jobst, Werner: Der römische Tempelbezirk auf dem Pfaffenberg/Carnuntum - The Roman Temple District of Pfaffenberg/Carnuntum. JOBST Media Präsentation Verlag, Klagenfurt 2006.

Kádár, Zoltán - Balla, Lajos: Savaria. Képzőmüvészeti Alap, Budapest 1958.

Lipps, Johannes: Transfer und Transformation römischer Architektur in den Nordwestprovinzen. In: Lipps, Johannes (ed.): Transfer und Transformation römischer Architektur in den Nordwestprovinzen. Tübinger Archäologische Forschungen 22. Rahden, Leidorf 2017. 13-31.

Mack, Rosamond E.: Bazaar to Piazza. University of California Press, Berkley, Los Angeles 2002.

Mátyás, József: Capitoliul de la Ulpia Traiana Sarmizegetusa - The Capitolium of Ulpia Traiana Sarmizegetusa. Buletinul Cercurilor Științifice Studențești 24 (2018) 1. 127-138

Moravánszky, Ákos - Lange, Torsten (eds.): Re-Framing Identities: Architecture's Turn to History, 1970-1990. Birkhäuser, Basel 2017.

Nemeth-Ehrlich, Dorica - Kušan Špalj, Dora: The Results of the Latest Excavations at the Roman Forum in Aquae Iasae - Varaždinske Toplice. In: Lazar, Irena (ed.): Religion in Public and Private Sphere. Acta of the 4th International Colloquium The Autonomous Towns of Noricum and Pannonia. Koper 2011. 211-232.

NN: Europhean Peripheries in Architectural Historiography. International Conference Session, Session chairs: Petra Brouwer, University of Amsterdam Kristina Jõekalda, Estonian Academy of Arts. In: European Architectural History Network. Fifth International Meeting, 13-16 June 2018, Tallinn, Programme and Abstracts. Estonian Academy of Arts, Tallinn 2018. 47-51.

Norberg-Schulz, Christian: Genius Loci. Landschaft, Lebensraum, Baukunst [Genius Loci. Landscape, Habitat, Architecture]. Klett-Cotta Verlag, Stuttgart 1982.

Özdengiz Başak, Meral - Peker, Ali Uzay: Szulejmán szultán türbe-palánkja Szigetváron a 2015/2016-os ásatások építészeti vizsgálatai alapján [The Türbe-Palisade of Sultan Suleiman in Szigetvár According to the Architectural Surveys of the Excavations in 2015/2016]. In: Pap, Norbert Fodor, Pál (eds.): Szulejmán Szultán Szigetváron. A szigetvári kutatások 2013-2016 között [Sultan Suleiman in Szigetvár. The Researches in Szigetvár between 2013-2016]. Hungarian Academy of Science - University of Pécs, Pécs 2017. 131-162.

Özgüven, Burcu: From the Ottoman Province to the Colony. Late Ottoman Educational Buildings in Nicosia. METU JFA 12 (2004) 1-2. 33-66.

Papp, Adrienn: The Position of the Buildings of Buda and Pest Dating to the Age of the Turkish Occupation of Hungary in the Architecture of the Ottoman Empire. In: Hitzel, Frederic (ed.): 14th International Congress of Turkish Art. College de France, Paris 2013. 591-598.

Paulovics, István: Savaria capitoliuma [The Capitolium of Savaria]. Archaeologiai Értesitö 3 (1940) $19-47$.

Pilsitz, Martin: Early Functionalism as a Design Principle of Historical Factory Buldings in Budapest. Épités - Épitészettudomány 41 (2013) 3-4. 349-371.

Pilsitz, Martin: A kőbányai Első Magyar Részvény Serfözde Rt. főzőháza. A bajor neobarokk sörfőzdék prototípusa [The First Hungarian Brewery Company's Mashhouse in Köbánya. A Prototype for the Neo-Baroque Breweries in Bavaria]. Épités - Épitészettudomány 43 (2015) 1-2. 79-94.

Pilsitz, Martin: Ötletek mozgásban. Az építészeti transzfer változatai [Ideas in Motion. The Variations of the Architectural Transfer]. Épités - Épitészettudomány 46 (2018) 3-4. 271-282.

Póczy, Klára - Czeglédy, Ilona: Archäologische Forschungen im Jahre 1966 [Archaeological Researches in the Year of 1966]. Archaeologiai Értesitö 94 (1967) 223.

Rabb, Péter: 'We are all servants here!' Mimar Sinan - Architect of the Ottoman Empire. Periodica Polytechnica Architecture 44 (2013) 1. 17-37.

Rendić-Miočević, Ante - Šegvić, Mirjana: Religions and Cults in South Pannonian Regions. In: Fitz Jenő (ed.): Religions and Cults in Pannonia. István Király Múzeum, Székesfehérvár 1998. 7-13

Roth, Paul W.: Industriespionage im Zeitalter der Industriellen Revolution [Industrial Espionage in the Age of the Industrial Revolution]. Blätter für Technikgeschichte 38 (1976) 40-54.

Šašel Kos, Marjeta: The Early Urbanization of Noricum and Pannonia. In: Zerbini, Livio (ed.): Roma e le province del Danubio. Soveria Mannelli, Rubbettino 2010. 209-230. 
Sedlmayr, János: A soproni római fórum bemutatása [The Introduction of the Roman Forum in Sopron]. In: Pamer, Nóra (ed.): Gerő László nyolcvanötödik születésnapjára. Müvészettörténet - Müemlékvédelem 6 (1994) 83-92.

Şenyurt, Oya: Kosova'da Murad Hüdavendigâr Türbesi ve Ek Yapıları [The Türbe of Sultan Murad in Kosovo, and Its Additional Buildings]. METU JFA 29 (2012) 2. 285-311.

Sinobad, Marko: Kapitolijski hramovi u Hrvatskoj - Capitoline Temples in Croatia. Opuscula Archaeologica 31 (2007) 221-263.

Sisa, József - Wiebenson, Dora (eds.): The Architecture of Historic Hungary. MIT Press, Massachusetts 1998.

Sudár, Balázs: Dzsámivá alakított templomok a hódoltságban [Converting Churches into Mosques in Ottoman Hungary]. In: Ittzés Gábor (ed.): Viszály és együttélés. Vallások és felekezetek a török hódoltság korában [Strife and Coexistence. Religions and Religious Denominations in Hungary in the Age of Ottoman Rule]. Universitas, Budapest 2018. 381-406.

Szakál, Ernő: Hitelesítő ásatást kér Scarbantia kapitóliumának temploma! [The Capitoline Temple of Scarbantia Requires Corroborant Excavation!]. Soproni Szemle 19 (1965) 4. 37-43.

Weber, Anna Marijke: Transformation räumlicher Prinzipen [Transformation of Spatial Principles]. http://arch.rwth-aachen.de/cms/Architektur/Forschung/Verbundforschung/Context-and-Form/ Projekte/Promotionen/ hzqr/Transformation-raeumlicher-Prinzipien (accessed 5 February 2019)

\section{TRANSZFER ÉS EXPORT AZ ÉPÍTÉSZETTÖRTÉNETBEN}

\section{HÁROM ESETTANULMÁNY A KÁRPÁT-MEDENCE TERÜLETÉRŐL}

\section{Összefoglaló}

Az olyan eset, amikor egy épülettípus eredeti kontextusából (a genius loci értelmében) átkerül egy, a kialakulási helyéhez képest idegen környezetbe, megegyezik az áttelepítés jelenségével. Amint azt az esettanulmányok mutatják, a kiváltott hatás nem feltétlen negatív, így a jelenséget sokkal inkább egy olyan külső impulzusként lehet értelmezni, amely befolyásolhatja a regionális építészeti fejlődést.

A tanulmány három szakaszban vizsgálja az alapvető építészettörténeti folyamatokat a Kárpátmedence területén. Az írás esettanulmányai a római kor építészetéből (Kr. u. 1-5. század), az oszmán hódoltság korszakából (Kr. u. 16-17. század) és az Osztrák-Magyar Monarchia-korabeli történeti ipari építészet (Kr.u. 19-20. század) témaköreiböl származnak. A Kárpát-medence Nyugat- és Kelet-Európa, valamint Észak-Európa és a Balkán-félsziget találkozási pontjában fekszik, és számos olyan államalakulat hatása érte, melynek központja e területen kívülre esett. A Római Birodalom, az Oszmán Birodalom és az Osztrák-Magyar Monarchia jelentős befolyást gyakorolt a vizsgált korszakok és terület építészetére.

Következésképp a területen a tárgyalt időszakokban a helyitől viszonylag eltérő, globális léptékü kultúra hatása vizsgálható, regionális összefüggésben. Ez az aspektus az építészettörténet aktuális kérdéseihez vezet: miként befolyásolja a regionális és globális építészeti tendenciák és tulajdonságok kölcsönhatása, valamint a központ, a félperiféria és a periféria kapcsolata az építészeti folyamatok vizsgálatát és az egyedi értékek megőrzését. Az esettanulmányok vizsgálatával a tanulmány az építészeti transzfer és az építészeti export kategóriáit vezeti be. A szerzők szándéka, hogy írásukkal további példákat bemutató diskurzust ösztönözzenek.

Kulcsszavak: építészeti transzfer, ipari építészet, a Capitoliumi Triász temploma, oszmán építészet, Kárpát-medence 


\title{
TRANSFER UND EXPORT IN DER BAUGESCHICHTE
}

\section{DREI FALLSTUDIEN AUS DER PANNONISCHEN TIEFEBENE}

\begin{abstract}
Zusammenfassung
Was wir heute Architekturgeschichte nennen, ist die bauliche Manifestation einer Vielzahl von Faktoren, die auf den vielschichtigen Entstehungsprozess von historischen Gebäuden Einfluss genommen haben. Einer dieser Einflussfaktoren ist der Architekturtransfer, im Sinne eines Austausches von Wissen über das Bauen, der zwischen Regionen, Ländern und Kontinenten wirksam war. Durch diese Erweiterung des Aktionsradius wurde die Wirksamkeit von Architektur in der Baugeschichte vom Regionalen zum Überregionalen vergrößert, ab dem 17. Jh. gar zum Globalen expandiert. Im Rahmen des vorgelegten Artikels kann das Thema nicht umfassend und abschließend aufgearbeitet werden. Vielmehr soll das Phänomen an Fallstudien aus drei verschiedenen Zeitepochen (Römische Bauten 1-5. Jh., Osmanische Bauten 16-17 Jh. und Industriegebäude 19-20. Jh.) des geografisch klar umgrenzten Gebietes der Pannonischen Tiefebene angesprochen und zur Diskussion gestellt werden. Ausgangspunkt der Überlegung ist die Frage, ob der Architekturtransfer hinsichtlich seiner Motivation und seines Mechanismus vom Architekturexport zu unterscheiden ist, oder dieser lediglich eine Variation des Transfers darstellt.
\end{abstract}

Schlüsselwörter: Architekturtransfer, Industrielles Erbe, Tempel der Kapitolinischen Trias, Osmanische Architektur, Karpatenbecken

Open Access statement. This is an open-access article distributed under the terms of the Creative Commons Attribution 4.0 International License (https://creativecommons.org/licenses/by/4.0/), which permits unrestricted use, distribution, and reproduction in any medium, provided the original author and source are credited, a link to the CC License is provided, and changes - if any - are indicated. (SID_1)

$\rightarrow$ Received: 21 February 2020. Accepted: 12 August 2020

First published online: 08 December 2020 